\title{
Keratinized Tadpole Cells in Human Oral Neoplasm: A Cytodiagnostic Approach
}

\author{
*Dr Abhimanyu Mohanta, Ph.D. ${ }^{1}$; Dr Prafulla K. Mohanty, Ph.D. ${ }^{2}$; \\ Dr Gadadhar Parida, M.D. ${ }^{3}$ \\ ${ }^{*}$.UGC Research Fellow, P.G. Department of Zoology, Utkal University, Vani Vihar, Bhubaneshwar, Odisha, \\ India-751 004. \\ ${ }^{2}$.Professor and Head, P.G. Department of Zoology, Utkal University, Vani Vihar, Bhubaneshwar, Odisha, \\ India-751 004. \\ ${ }^{3}$ Former Director, Professor and Head, Department of Oncopathology, Acharya Harihar Regional Cancer \\ Centre (AHRCC), Cuttack, Odisha, India-753 007.
}

\begin{abstract}
:
Background: Use of exfoliative cytology and cyto-analysis is a useful early diagnostic method for epithelial atypia and for human oral neoplasm. A rare occurrence of cytological atypia appeared to be anuran tadpole larva, named as keratinized tadpole cell (KTC) is analyzed cytomorphometrically with a cytodiagnostic approach.

Materials and Methods: In a case-control study, exfoliated scraped cytosmears were collected from the affected sites of the clinically diagnosed 136 oral cancer patients over the pre-cleaned microslides and immediately fixed in acetoalcohol. Cytosmears were stained with routine Papanicolaou's stain and counterstained with the Giemsa's solution. One thousand cells were observed and the KTCs were scored from each stained sample following standard criteria. Findings were statistically analyzed, interpreted and correlated with the oral sites, sex and nature of addiction.

Results: Keratinized tadpole cells (KTCS) exhibit both cytological and nuclear pleomorphism. Almost all KTCs are moderately differentiated with a well defined head and tail in each. Usually, nucleus is confined to the head part of the cell and tail contains cytoplasm only. Keratinized cytoplasm, nuclear pleomorphism, presence of nuclear haloes, micronucleation, multinucleation and increased nuclear-cytoplasmic ratios $(N / C)$ in keratinized tadpole cells are the clear indication of malignancy so far as cytopathology is concerned.

Conclusion: Appearance of KTCS in the epithelia of oral neoplasm has a practical utility in early detection and diagnosis of the oral cancer patients.
\end{abstract}

Key words: Cytodiagnosis, cytopathology, cytosmear, exfoliative cytology, keratinized tadpole cell, nuclearcytoplasmic (N/C) ratios, pleomorphism

\section{Introduction}

Oral cancer is one of the most common cancers on a worldwide basis with a higher incidence. It account for 2 per cent of the cancer burden worldwide (an estimated 263,000 cases in 2008), but it is the second most common cancer in males and the fourth most common cancer in females in South-Central Asia, accounting for 7 per cent of the total cancers diagnosed in this region in 2008 [1]. In India, oral cancer ranks in the top three which accounts for over thirty per cent of all cancers reported in the country [2]. Since, the oral cavity is more accessible to complete examination it could be used in early detection of precancerous and cancerous lesions. But, either due to ignorance or inaccessibility of medical care, the disease gets detected in the later stages. As a result, the survival index continues to be small (50 per cent), as compared to the progress in diagnosis and treatment of other malignant tumors [3].

Oral exfoliative cytology is used to examine exfoliated cells from the surface of the oral mucosa. Miller et al. were the first to study the cytology of the normal oral epithelium [4]. Alterations in the epithelial cells serve as reliable indicators of dysplastic or neoplastic changes. Montgomery and his associates applied the principle of exfoliative cytology for the diagnosis of oral cancer [5]. Use of exfoliative cytology and cytoanalysis is a useful early diagnostic method for epithelial atypia and for oral lesion. Clinical cytology, in the hands of well trained personnel now possesses a sensitivity of 92 to 100 per cent while its specificity has risen to somewhere between 97 to 100 per cent [6]. This itself is a guarantee that cytodiagnosis is likely to yield a high degree of accuracy in cases of oral malignancies.

In the present study, the frequency of keratinized tadpole cells (KTCs) in human oral exfoliated scrape smears of normal, precancerous and cancerous epithelia have been scored, statistically analyzed and interpreted to assess its applicability in diagnosing early detection of human oral carcinoma. 


\section{II.1. Collection of samples}

\section{Materials and Method}

Exfoliated scrape smears were collected from the clinically diagnosed 136 patients suffering from precancerous lesions and oral squamous cell carcinoma (OSCC) at the Out Patient Department (OPD) of Acharya Harihar Regional Cancer Center (AHRCC), Cuttack, Odisha, during May 2007-May 2009. Smearing was done on the pre-cleaned-coded microslides and the slides were fixed in aceto-alcohol (1:3) fixative, immediately. On the basis of International Classification of Diseases (ICD-10) by World Health Organization (WHO), two slides were smeared and prepared from each affected sites of the patient. Prior to the collection of samples, case-history of the patients related to their age, sex, food, habits, oral hygiene and occupation were asked and recorded for detail analysis. Out of 136 patients, 126 ( 92.65 per cent) were addicted to different forms of tobacco and alcohol for more than 15 years and 10 (7.35 per cent) were absolutely non-addicted. A parallel set of 136 samples were also collected from the non-addicted and non-cancerous individuals from different regions of Odisha which are called as control group. This study was approved by Subject Research Committee (SRC) of Utkal University, Bhubaneshwar, Odisha, India and necessary permission was also obtained from the Director, AHRCC, Cuttack, Odisha, India.

\section{II.2. Staining protocol and scoring of KTCs}

Wet fixed smears were stained by adopting Papanicolaou's staining protocol and counterstained with the Giemsa's solution.. One thousand cells were observed and the KTCs were scored from each stained sample following standard criteria. Findings were statistically analyzed, interpreted and correlated with the age, sex, oral sites and nature of addiction.

\section{II.3 Statistical analyses}

The mean length and breadth of the KTC was taken into account as length and breadth of the respective KTC, as each cell was measured at three different regions (middle and on its either sides) - in length and breadth-wise by using computer-assisted Cat Cam: Microscope camera of Catalyst Biotech ${ }^{\circledR}$. The measured values were tabulated. The nuclear-cytoplasmic ratio $(\mathrm{N} / \mathrm{C})$ was calculated after taking the area of the cytoplasm $(\mathrm{C})$ and nucleus $(\mathrm{N})$ of the respective cell. The findings were statistically analyzed and interpreted with respect to oral sites, sexes and nature of addiction.

\section{Results}

Exfoliated normal squamous cells of the oral cavity are mostly angulated and polyhedral in shape. Generally, the thickness of the squamous cell was negligible in relation to its length and breadth. They are, seen in smears as flat and polyhedral cells with a centrally placed rounded or oval nucleus in each. Variations occur in staining of the exfoliated mature normal cells, such as sky blue in Papanicolaou's stain (Fig.1) and magenta colour in Giemsa's stain (Fig.2). But, a unique type cytological atypia, named as keratinized tadpole cell (KTC) was observed only in 49 (36.03 per cent) cases of stained microslides prepared from the exfoliated scraped cytosmears collected from the oral cancer patients. As the name suggests, morphologically, the KTC appears to be an anuran tadpole larva having a large oval head and a long tail (Figs.3-5). Really, it is a true metamorphosis of the normal oral squamous cell (NOSC) into a tadpole cell during oral carcinogenesis. Except few, in most cases the cytoplasm of the KTC was observed to be hyperkeratinized all along its length and breadth. Nucleus was either rounded or oval, enlarged hyperchromatic and confined to the head region only. In few cases, the cytoplasms of the KTCs were hypokeratinized and nuclei were flattened to be a ribbon form and extended towards the tail region (Fig.6). Bi-nucleated and multinucleated KTCs were also observed in the stain ed cytosmears (Figs.7-8). It is important to note that exceptionally in 3 (2.21 per cent) cases, the nuclei were observed to be extended up to the tip of the tail. In such cases, the tadpole cells were found to be non-keratinized, may be either due to lack or scanty of cytoplasm or increase of nuclear material and thus, the extended nuclei cover the whole cell- both head and tail (Figs.9-11). Nuclear anomalies, like nuclear pleomorphism, uneven distribution of nuclear content, appearance of nuclear haloes, micronucleation and multinucleation in such cells are the clear indication of frank malignancy. 


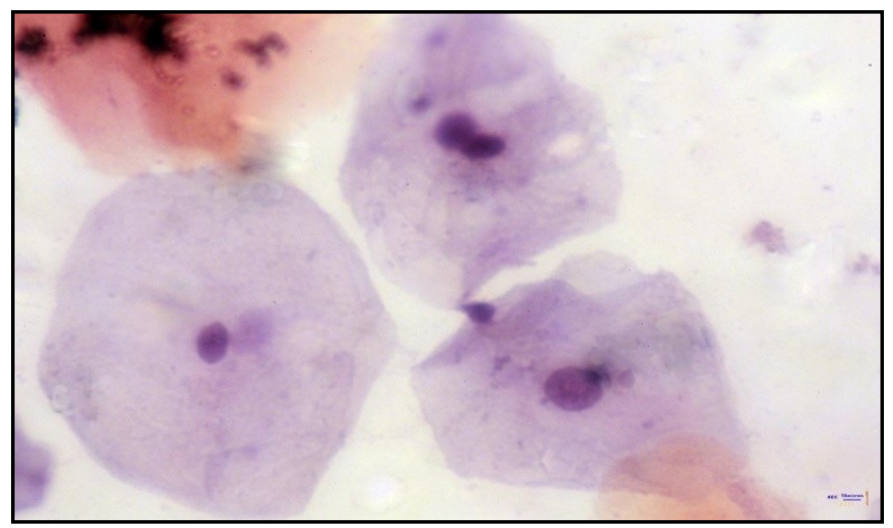

Figure 1 Exfoliated normal oral squamous cells (Papanicolaou's stain $x 400$ ).

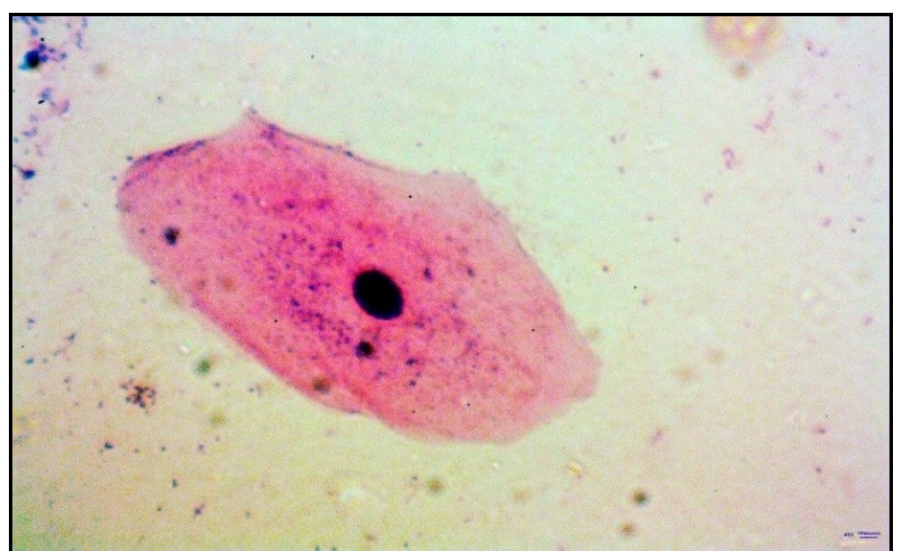

Figure 2 An exfoliated normal oral squamous cell (Giemsa's stain x 400).

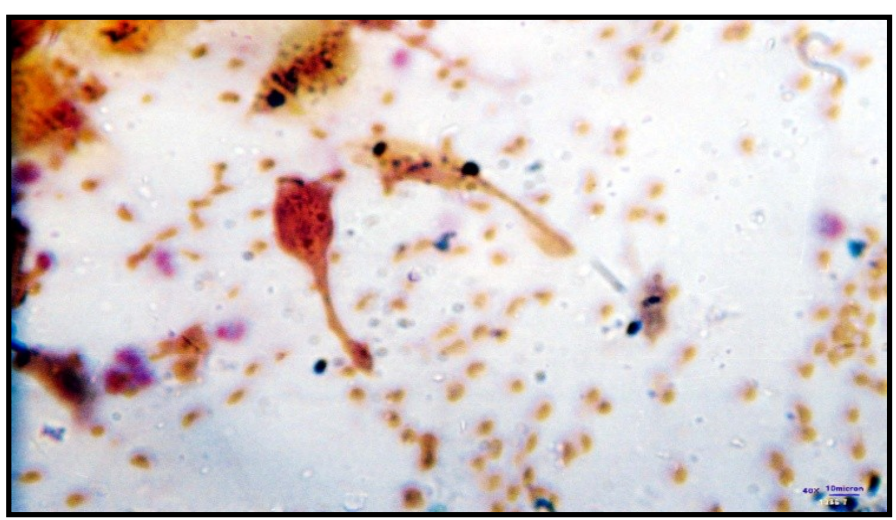

Figure 3 A pair of keratinized tadpole cells with hypo- and hyperkeratinization.

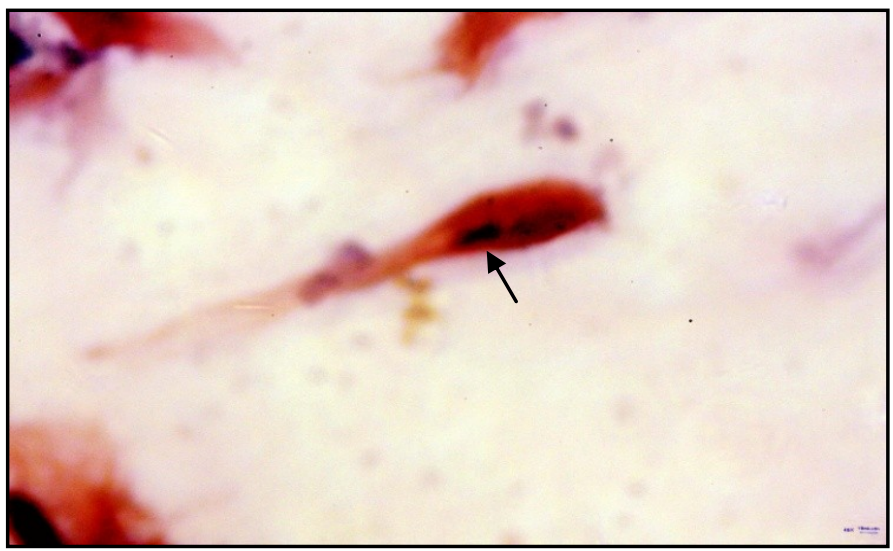

Figure 4 A keratinized tadpole cell with an elongated nucleus in head region. 


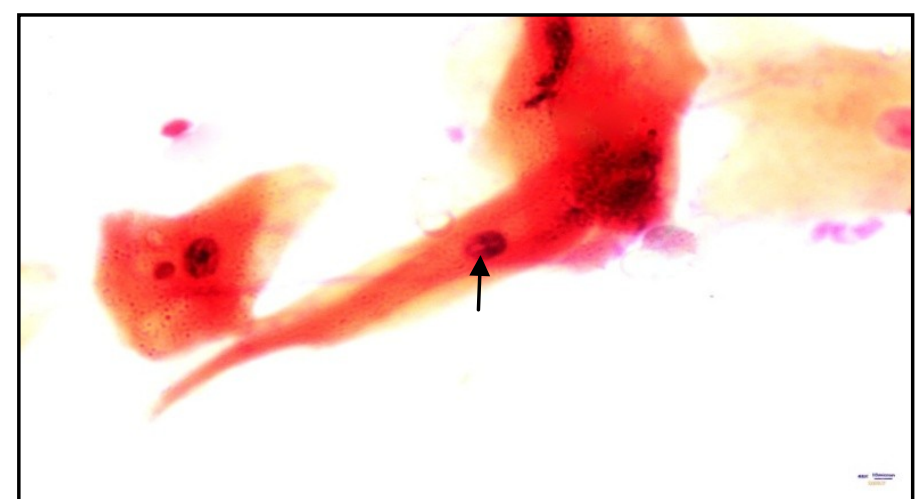

Figure 5 A hyperkeratinized tadpole cell with a nuclear halo.

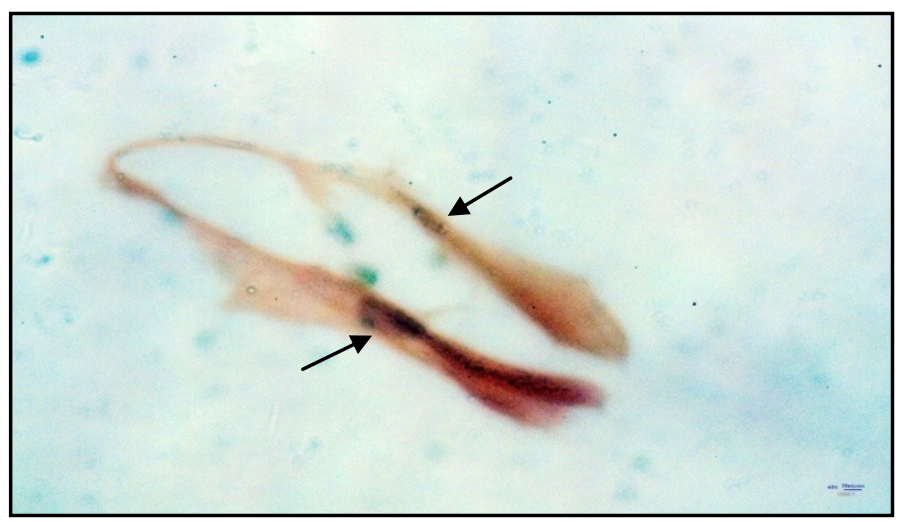

Figure 6 A pair of keratinized tadpole cells with a nucleus at the tail region (upper) and elongation and shifting of the nucleus towards the tail (lower).

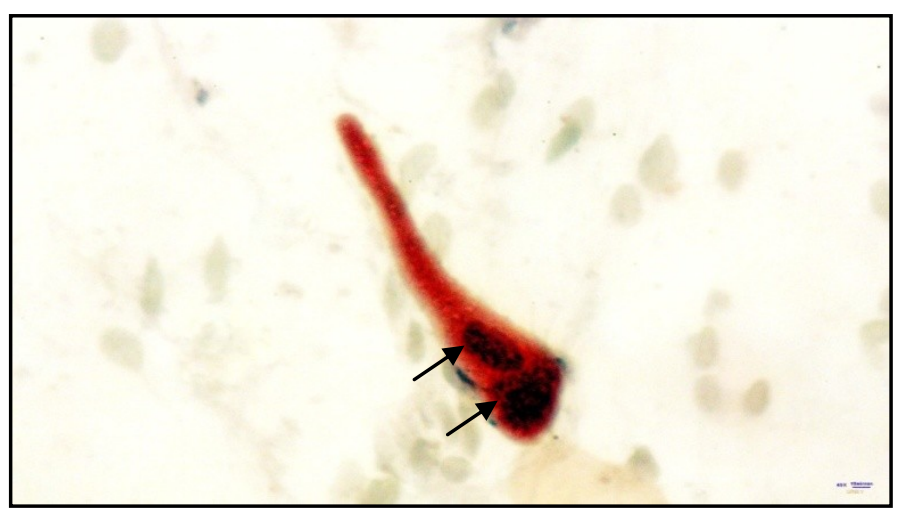

Figure 7 A binucleated keratinized tadpole cell with an enlarged nucleus in the apical part of the head region.

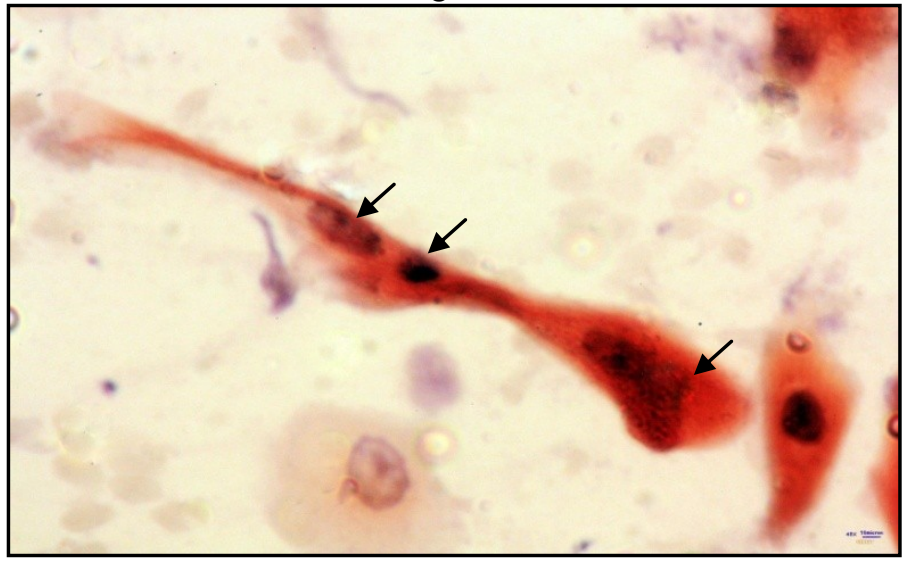

Figure 8 A multinucleated keratinized tadpole cell with an irregular boundary. 


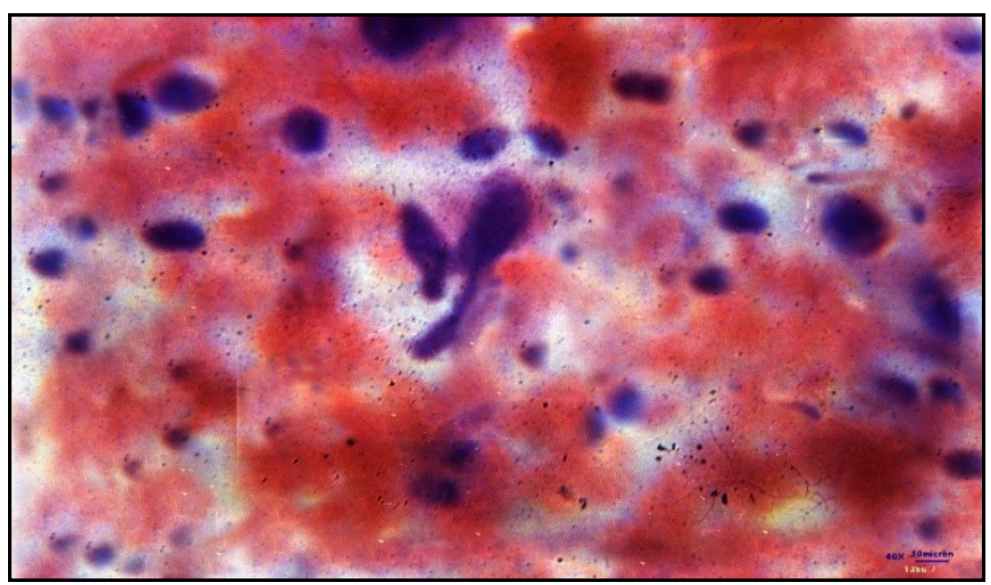

Figure 9 A non-keratinized tadpole cell with an elongated dense nucleus extended up to the tail region.

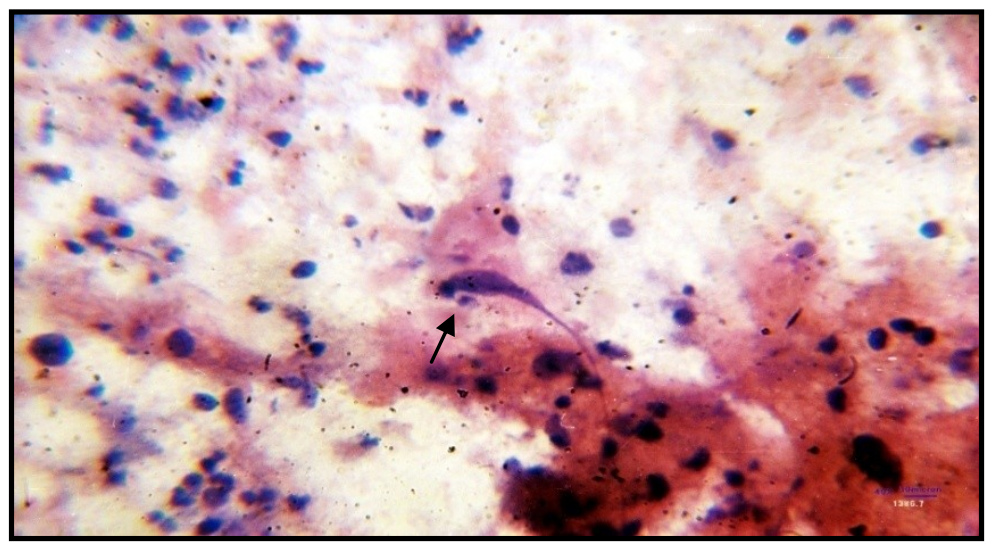

Figure 10 A microncleated non-keratinized tadpole cell with an elongated dense nucleus extended up to the tip of the tail region.

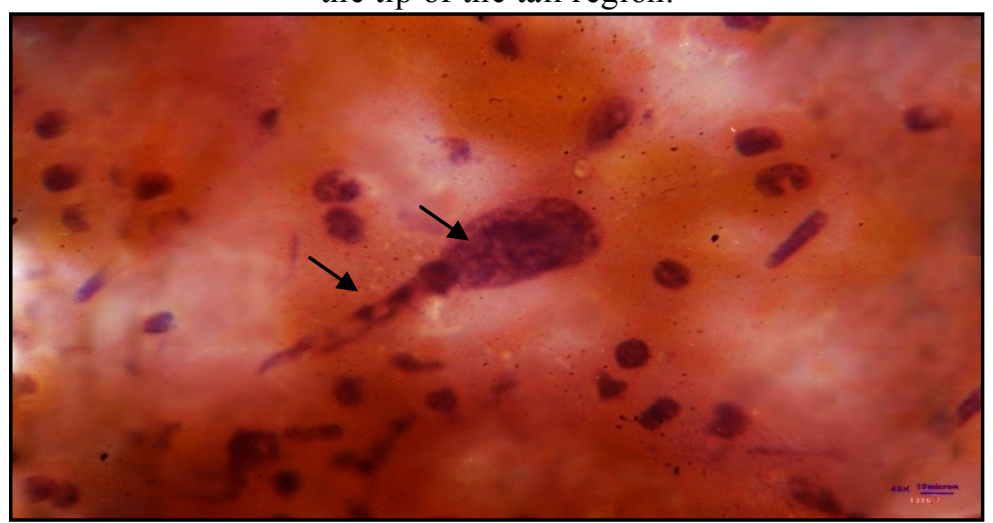

Figure 11 A non-keratinized tadpole cell with nuclear haloes and ill defined cell boundary.

The KTCs are moderately differentiated and found in the premalignant and malignant oral epithelia. Numerically, their number was very less in comparison with the other cytological atypias in our study. The total number of keratinized tadpole cells scored was 122 from the 29 (35.37 per cent) samples of 82 males and 111 KTCs from 20 (37.04 per cent) samples 54 female cases (Table 1).

With reference to the specific oral site and age group, the highest number of keratinized tadpole cells ( 35 in males and 40 in females) were scored from the buccal (cheek) mucosa in the age group of 5069 years (Fig.12). Not only that the highest percentage of keratinized tadpole cells (53.3 per cent in males and 64.9 per cent in females) were also recorded from the buccal mucosa of 8 males and 7 females (Fig.13). In our study, another interesting fact come into light that KTCs were frequently observed in the cytosmears of 10 (90.9 per cent) out of 11 male lingual patients and 5 ( 71.43 per cent) out of 7 female lingual patients (Table 1) which indicates that tongue is the KTCs-prone site during lingual carcinogenesis. In addition to that, rare appearance of non-keratinized tadpole cells in the epithelia of tongue in the agegroup of 50-69 years of multiple addicted male individuals demands further research. 
Table 1 Oral site, age group and sex-wise scored keratinized tadpole cells (KTCs)

\begin{tabular}{|c|c|c|c|c|c|c|c|c|c|c|}
\hline \multirow{2}{*}{ No } & \multirow{2}{*}{$\begin{array}{c}\text { Sites } \\
(\mathrm{ICD}-10)\end{array}$} & \multirow{2}{*}{$\begin{array}{l}\text { Age } \\
\text { groups } \\
\text { in } \\
\text { years }\end{array}$} & \multicolumn{2}{|c|}{ No. of samples } & \multicolumn{2}{|c|}{ No. of samples with KTCs } & \multicolumn{2}{|c|}{ KTCs scored } & \multicolumn{2}{|c|}{$\begin{array}{c}\text { Total no of KTCs } \\
\text { scored }(\%) \\
\end{array}$} \\
\hline & & & Male & Female & Male & Female & Male & Female & Male & Female \\
\hline \multirow{3}{*}{1} & \multirow{3}{*}{ Lip } & $30-49$ & 2 & Nil & 1 & $\mathrm{Ni}$ & 1 & Nil & \multirow{3}{*}{$\begin{array}{c}2 \\
(1.6)\end{array}$} & \multirow[t]{3}{*}{$\begin{array}{c}3 \\
(2.7)\end{array}$} \\
\hline & & $50-69$ & 2 & 4 & 1 & 1 & 1 & 2 & & \\
\hline & & $70-89$ & 1 & 2 & Nil & 1 & Nil & 1 & & \\
\hline \multirow{3}{*}{2} & \multirow{3}{*}{ Tongue } & $30-49$ & 5 & 2 & 4 & 1 & 11 & 2 & \multirow[t]{3}{*}{$\begin{array}{c}28 \\
(22.9)\end{array}$} & \multirow[t]{3}{*}{$\begin{array}{c}12 \\
(10.8)\end{array}$} \\
\hline & & $50-69$ & 5 & 4 & 5 & 3 & 14 & 8 & & \\
\hline & & $70-89$ & 1 & 1 & 1 & 1 & 3 & 2 & & \\
\hline \multirow{3}{*}{3} & \multirow{3}{*}{$\begin{array}{l}\text { Alveolus } \\
\text { and } \\
\text { gingiva }\end{array}$} & $30-49$ & 4 & 3 & 1 & 1 & 1 & 2 & \multirow{3}{*}{$\begin{array}{c}2 \\
(1.6)\end{array}$} & \multirow{3}{*}{$\begin{array}{c}7 \\
(6.3)\end{array}$} \\
\hline & & $50-69$ & 8 & 3 & 1 & 1 & 1 & 5 & & \\
\hline & & $70-89$ & 4 & Nil & Nil & Nil & Nil & Nil & & \\
\hline \multirow{3}{*}{4} & \multirow{3}{*}{$\begin{array}{c}\text { Floor of } \\
\text { the } \\
\text { mouth }\end{array}$} & $30-49$ & 4 & 1 & 1 & 1 & 4 & 1 & \multirow{3}{*}{$\begin{array}{c}8 \\
(6.6)\end{array}$} & \multirow{3}{*}{$\begin{array}{c}3 \\
(2.7)\end{array}$} \\
\hline & & $50-69$ & 2 & 4 & 1 & 1 & 2 & 2 & & \\
\hline & & $70-89$ & 1 & 1 & 1 & Nil & 2 & Nil & & \\
\hline \multirow{3}{*}{5} & \multirow{3}{*}{ Palate } & $30-49$ & 4 & 1 & 2 & 1 & 5 & 4 & \multirow[t]{3}{*}{$\begin{array}{c}17 \\
(14.0)\end{array}$} & \multirow[t]{3}{*}{$\begin{array}{c}14 \\
(12.6)\end{array}$} \\
\hline & & $50-69$ & 1 & 2 & 1 & 1 & 6 & 10 & & \\
\hline & & $70-89$ & 1 & Nil & 1 & Nil & 6 & Nil & & \\
\hline \multirow{3}{*}{6} & \multirow{3}{*}{$\begin{array}{l}\text { Buccal } \\
\text { mucosa }\end{array}$} & $30-49$ & 14 & 4 & 3 & 1 & 23 & 14 & \multirow[t]{3}{*}{$\begin{array}{c}65 \\
(53.3)\end{array}$} & \multirow[t]{3}{*}{$\begin{array}{c}72 \\
(64.9)\end{array}$} \\
\hline & & $50-69$ & 16 & 19 & 4 & 4 & 35 & 40 & & \\
\hline & & $70-89$ & 7 & 3 & 1 & 2 & 7 & 18 & & \\
\hline & Total & $30-89$ & 82 & 54 & 29 & 20 & 122 & 111 & 122 & 111 \\
\hline
\end{tabular}

Source: Primary data. Figures in parentheses indicate relative percentage of the KTCs.

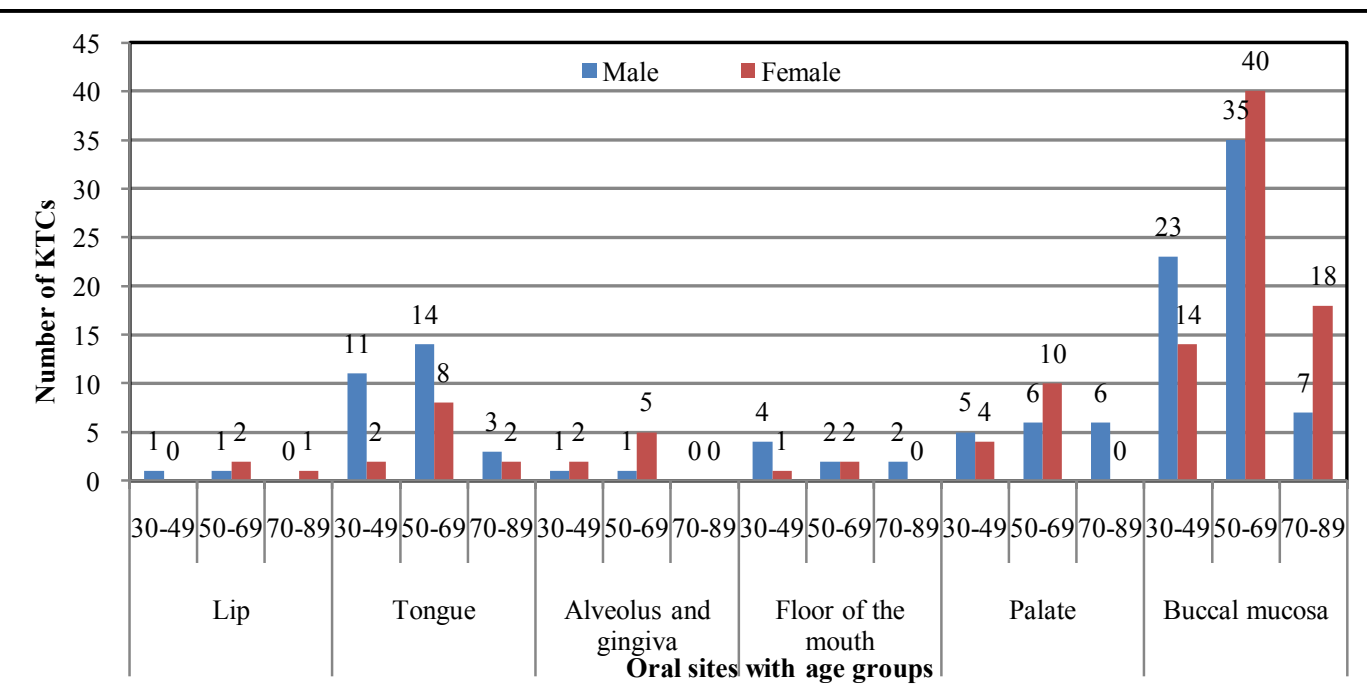

Figure 12 Oral site, age group and sex-wise enumeration of keratinized tadpole cells. 


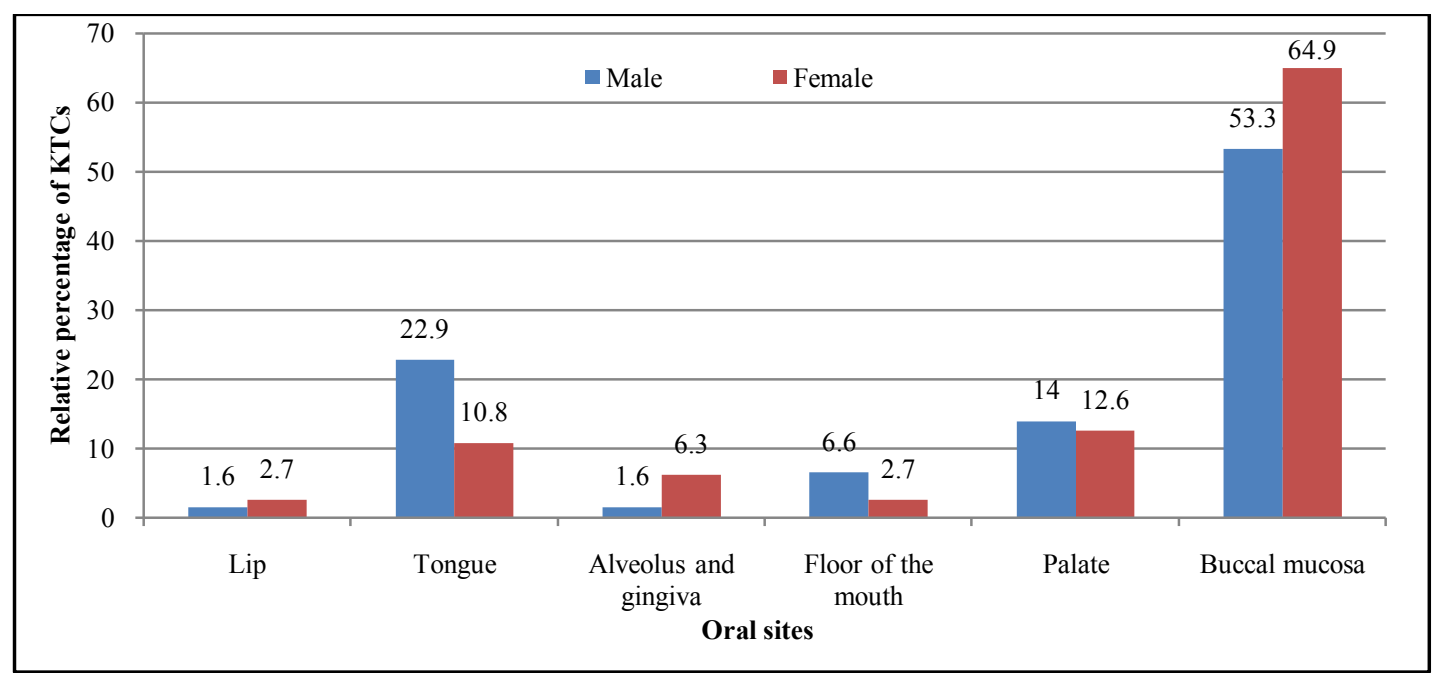

Figure 13 Relative percentages of KTCs with respect to oral sites and sex.

On account of cytomorphometrical analysis, earlier we reported that the mean length and breadth of the normal squamous cells in males (Table 2$)$ were $86.50 \mu \mathrm{m}( \pm 17.234 \mu \mathrm{m})$ and $64.23 \mu \mathrm{m}( \pm 12.125 \mu \mathrm{m})$ respectively having an area of $5555.89 \mu \mathrm{m}^{2}\left( \pm 208.362 \mu \mathrm{m}^{2}\right)$. The nucleus of the normal squamous cell in male was measured to be $12.95 \mu \mathrm{m}( \pm 3.368 \mu \mathrm{m})$ in length and $12.43 \mu \mathrm{m}( \pm 3.235 \mu \mathrm{m})$ in breadth with an area of $160.968 \mu \mathrm{m}^{2}\left( \pm 10.895 \mu \mathrm{m}^{2}\right)$. The nuclear-cytoplasmic ratio (N/C) in males was calculated to be $1: 34.5$. In case of females (Table 2), the mean length, breadth and area of the squamous cells were recorded to be $85.895 \mu \mathrm{m}( \pm 16.374 \mu \mathrm{m}), 65.012 \mu \mathrm{m}( \pm 11.876 \mu \mathrm{m})$ and $5582.905 \mu \mathrm{m}^{2}\left( \pm 194.457 \mu \mathrm{m}^{2}\right)$ respectively. The mean length and breadth of the nucleus were $12.920 \mu \mathrm{m}( \pm 3.544 \mu \mathrm{m})$ and $12.530 \mu \mathrm{m}( \pm 3.452 \mu \mathrm{m})$. Thus, the mean nuclear area of the normal squamous cells in females was found to be $161.887 \mu \mathrm{m}^{2}\left( \pm 12.233 \mu \mathrm{m}^{2}\right)$. Hence, the nuclear-cytoplasmic $(\mathrm{N} / \mathrm{C})$ ratio was found to be 1:34.4 in females [8].

The KTCs in males (Table 2) were measured to be $109.557 \mu \mathrm{m}( \pm 35.432 \mu \mathrm{m})$ in length having mean length of head was $34.965 \mu \mathrm{m}( \pm 13.230 \mu \mathrm{m})$ and tail was $74.592 \mu \mathrm{m}( \pm 25.432 \mu \mathrm{m})$. The mean breadth of the head of the cell was $18.927 \mu \mathrm{m}( \pm 3.237 \mu \mathrm{m})$ and the tail was $4.144 \mu \mathrm{m}( \pm 1.101 \mu \mathrm{m})$ and the cytoplasmic area was calculated to be $2228.024 \mu \mathrm{m}^{2}\left( \pm 114.402 \mu \mathrm{m}^{2}\right)$. The mean length, breadth and area of the nucleus of the KTCs was found to be $13.209 \mu \mathrm{m}( \pm 2.324 \mu \mathrm{m}), 10.247 \mu \mathrm{m}( \pm 1.217 \mu \mathrm{m})$ and 135.352 $\mu \mathrm{m}^{2}\left( \pm 2.828 \mu \mathrm{m}^{2}\right)$. The $\mathrm{N} / \mathrm{C}$ ratio of this cell was calculated to be $1: 16.4$ in males. In case of females, the mean length and breadth of the KTCs was found to be $96.125 \mu \mathrm{m}( \pm 33.625 \mu \mathrm{m})$ and $18.734 \mu \mathrm{m}$ $( \pm 3.122 \mu \mathrm{m})$, respectively. The head part of the KTCs was measured to be $35.213 \mu \mathrm{m}( \pm 6.357 \mu \mathrm{m})$ in length and $26.734 \mu \mathrm{m}( \pm 3.122 \mu \mathrm{m})$ in breadth. The tail was measured to be $61.912 \mu \mathrm{m}( \pm 3.625 \mu \mathrm{m})$ in length and $3.970 \mu \mathrm{m}( \pm 2.435 \mu \mathrm{m})$ in breadth. The total mean area of the KTCs was measured to be $1794.950 \mu \mathrm{m}^{2}( \pm 104.977)$. The nuclear length, breadth and area were calculated to be $12.786 \mu \mathrm{m}( \pm 3.405$ $\mu \mathrm{m}), 8.341 \mu \mathrm{m}( \pm 2.221 \mu \mathrm{m})$, and $106.648 \mu \mathrm{m}^{2}\left( \pm 7.562 \mu \mathrm{m}^{2}\right)$ respectively. Thus, the $\mathrm{N} / \mathrm{C}$ ratio was found to be 1:16.8 in females (Fig.14).

Table 2 Cytomorphometric analysis of Normal oral squamous cell (NOSC) and keratinized tadpole cells (KTCs)

\begin{tabular}{|c|c|c|c|c|c|c|c|c|c|}
\hline \multirow{2}{*}{$\begin{array}{l}\text { Cell } \\
\text { type }\end{array}$} & \multirow[t]{2}{*}{ Sex } & \multirow{2}{*}{$\begin{array}{l}\text { No of } \\
\text { cells } \\
\text { scored }\end{array}$} & \multicolumn{3}{|c|}{ Cytoplasm (C) } & \multicolumn{3}{|c|}{ Nucleus (N) } & \multirow{2}{*}{$\begin{array}{c}\mathrm{N} / \mathrm{C} \\
\text { Ratio }\end{array}$} \\
\hline & & & $\begin{array}{c}\text { Mean } \\
\text { length in } \\
\mu \mathrm{m} \pm \mathrm{SD}\end{array}$ & $\begin{array}{c}\text { Mean } \\
\text { breadth in } \\
\mu \mathrm{m}+\mathrm{SD}\end{array}$ & $\begin{array}{l}\text { Mean area } \\
\text { in } \\
{\mu \mathrm{m}^{2}+\mathrm{SD}}^{2}\end{array}$ & $\begin{array}{c}\text { Mean } \\
\text { length in } \\
\mu \mathrm{m}+\mathrm{SD}\end{array}$ & $\begin{array}{c}\text { Mean } \\
\text { breadth in } \\
\mu \mathrm{m}+\mathrm{SD}\end{array}$ & $\begin{array}{l}\text { Mean area } \\
\text { in } \\
\mu \mathrm{m}^{2} \pm \mathrm{SD}\end{array}$ & \\
\hline \multirow{2}{*}{ NOSC } & Male & 1000 & $\begin{array}{r}86.50 \\
+2.234 \\
\end{array}$ & $\begin{array}{c}64.23 \\
+2.125 \\
\end{array}$ & $\begin{array}{c}5555.89 \\
\pm 4.747 \\
\end{array}$ & $\begin{array}{r}12.95 \\
\pm 1.368 \\
\end{array}$ & $\begin{array}{c}12.43 \\
\pm 1.235 \\
\end{array}$ & $\begin{array}{c}160.968 \\
\pm 1.689 \\
\end{array}$ & $1: 34.5$ \\
\hline & Female & 1000 & $\begin{array}{r}85.875 \\
\pm 2.370 \\
\end{array}$ & $\begin{array}{r}65.012 \\
\pm 1.876 \\
\end{array}$ & $\begin{array}{c}5582.905 \\
\pm 4.446 \\
\end{array}$ & $\begin{array}{r}12.92 \\
\pm 1.540 \\
\end{array}$ & $\begin{array}{r}12.53 \\
\pm 1.450 \\
\end{array}$ & $\begin{array}{c}161.887 \\
\pm 2.233\end{array}$ & $1: 34.4$ \\
\hline \multirow{2}{*}{ KTC } & Male & 122 & $\begin{array}{r}109.55 \\
\pm 5.342\end{array}$ & $\begin{array}{r}18.927 \\
\pm 3.237\end{array}$ & $\begin{array}{r}2228.02 \\
\pm 20.514\end{array}$ & $\begin{array}{r}13.209 \\
\pm 1.324\end{array}$ & $\begin{array}{c}8.547 \\
\pm 1.217\end{array}$ & $\begin{array}{r}112.89 \\
\pm 7.567\end{array}$ & $1: 19.7$ \\
\hline & Female & 111 & $\begin{array}{r}96.125 \\
\pm 3.625\end{array}$ & $\begin{array}{r}18.734 \\
\pm 3.122 \\
\end{array}$ & $\begin{array}{r}1794.95 \\
\pm 26.796 \\
\end{array}$ & $\begin{array}{r}12.786 \\
\pm 3.405 \\
\end{array}$ & $\begin{array}{c}8.341 \\
\pm 2.221 \\
\end{array}$ & $\begin{array}{c}106.648 \\
\pm 7.567\end{array}$ & $1: 16.8$ \\
\hline
\end{tabular}

Source: Primary data 


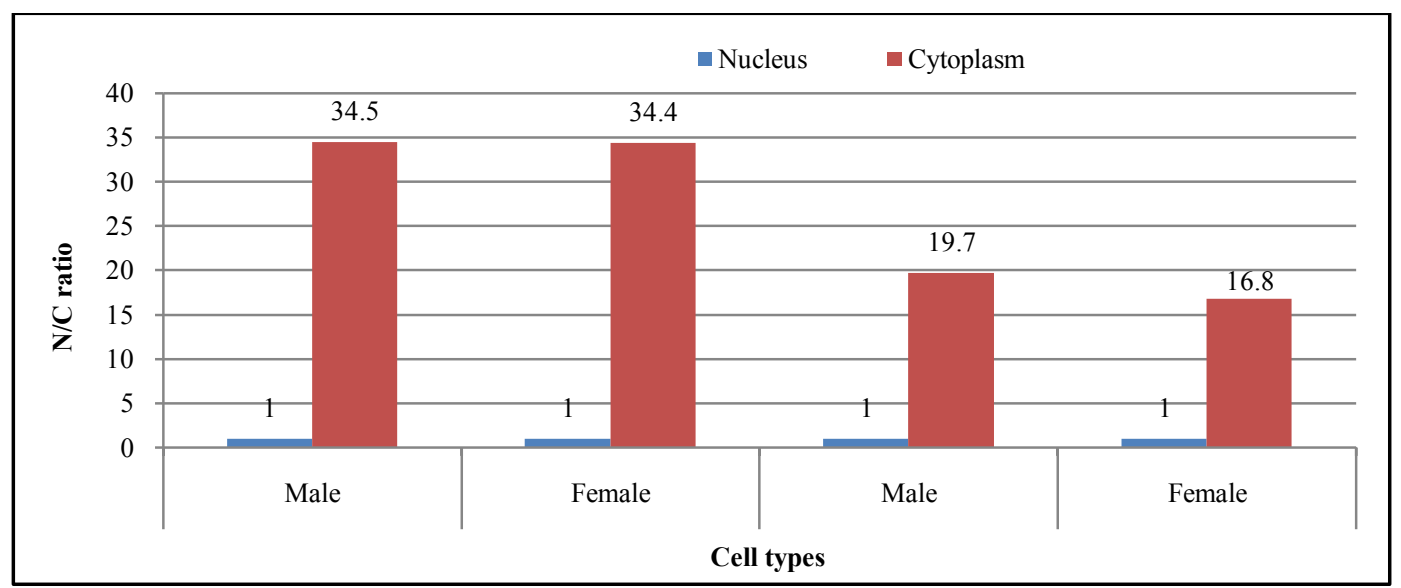

Figure 14 Sex-wise N/C ratios in NOSCs and KTCs.

\section{Discussion}

Cytology is a reliable diagnostic tool in diagnosis of presence or absence of malignancy in a lesion with high accuracy rate. Silverman et al. have suggested that cytologic technique, being simple and less injuryproducing procedure, has the advantage of doing away with many undersirable features of a biopsy and that offers a simple yet reliable method of great predictability in cancer detection programme [9]. Recently, Mulki et al. have reported that the computer-assisted exfoliative cytology (oral CDX) is considered as an accurate method for detecting premalignant and malignant buccal lesions. Cytomorphometric analysis of smears obtained with oral rinse can serve as a convenient screening tool in detection of OSCC cases [10]. In this study also exfoliated scraped cytosmears from the epithelia of oral neoplasms were used and cytomorphometric analysis of rarely occurred keratinized tadpole cells (KTCs) was undertaken.

Many workers have reported earlier on the occurrence of the tadpole cells in oral smears. Cawson found tadpole cell less common (only in 1 case) in smears of oral carcinoma [11]. King also found tadpole cells and fiber cells only in 2 cases of his series [12]. Pande et al. have reported that in the cytological smears through FNAC from the Rhabdomyosarcoma of the oral cavity lesion revealed high cellularity of small groups and predominantly single cells of the spindle cell type, tadpole type, and plump round cells. Cells had large hyperchromatic nuclei with prominent nucleoli and abundant well-defined eosinophilic cytoplasm. Tumor giant cells as well as large number of mitotic figures and many binucleated cells were seen. Features were suggestive of a malignant mesenchymal tumor. Considering the age of the patient and the cytological details, a diagnosis of pleomorphic rhabdomyosarcoma was given [13]. Histopathological examination of the orofacial and neck soft tissue tumors was also reviewed by Akinbami et al. and reported that pleomorphic cells such as malignant round and spindle muscle cells, tadpole cells and prominent mitotic figures were observed in rhabdomyosarcoma cases [14].

Singh has reported that the smear revealed inflammatory cells in 100 per cent, malignant cells in 75 per cent cases either in groups or in singles. The third type of cells $60 \%$, the undifferentiated cells 37 per cent, and tadpole cells were the least commonly encountered cells and seen only in one i.e. in 5 per cent cases. In his study, 75 per cent cases were positive for cancer, 10 per cent were suspicious for cancer and remaining 15 per cent were given as negative for cancer [15]. In a study of pleomorphic adenoma, cytological smears revealed moderately atypical squamous cells, clumps of keratin material, necrosis, inflammatory cells and macrophages along with bland epithelial and myo-epithelial cell in fibromyxoid stroma. Few clusters of overcrowded squamous cells showed moderate to marked pleomorphism, hyperchromatic nuclei, prominent nucleoli, and moderate cytoplasm. Many dispersed tadpole-like squamous cells showed hyperchromatic and irregular nuclei with keratinized cytoplasm [16].

Majority of the carcinomas of the oral cavity are either of well differentiated or moderately differentiated squamous cell type. In these type of cases, the malignant cells have a characteristic cytologic appearance and are usually quite easily recognized [17]. From the results achieved by workers like Sandler, it seems there is a great promise in its use in oral premalignant and in-situ carcinomas [18,19]. But, why do oral cells exhibit such a huge cytological pleomorphism (?)- is an intriguing and a thought-provoking question. Ponte'n et al. have suggested that tissue specificity is achieved by precise regulation of protein levels in space and time, and that different tissues in the body acquire their unique characteristics by controlling not which proteins are expressed but how much of each is produced. Their findings also suggested that few proteins are 
expressed in a cell type-specific manner, and that the phenotype and function of a cell is determined by localization and fluctuations in concentration of a large portion of the proteome [20]. Earlier we reported that the pattern of keratinization in different cytological atypias detected in exfoliated cytosmears of human oral carcinoma [21]. Recently, Vaidya and Kanojia have reported that keratin 16 and keratin 10, which are markers of cell proliferation and cell differentiation, respectively, themselves appear to regulate cell proliferation/ differentiation [22]. In the present study, the rarely detected pleomorphic keratinized tadpole cells are observed to be hypo- or hyper-keratinized, moderately differentiated and exhibited nuclear pleomorphism. Well demarcated prominent head usually with a single nucleus (or multinucleated condition) and an elongated tail mimic to an anuran tadpole larva is really a unique cytological atypia in the epithelia of oral neoplasm approaching cytodiagnostic significance. Exceptionally, rare appearance of non-keratinized tadpole cells in the epithelia of tongue in the age-group of 50-69 years of multiple addicted male individuals demands further research.

McKinley categorically stated that the nucleus is the cytogenetic house of the cell. The morphologic changes found in the nucleus reflect overall cellular activity; therefore, these should be interpreted in conjunction with the changes in other cellular compartments. Particularly, irregularities in nuclear membrane called 'nuclear membrane irregularities' are an end result of transformation and are reliable indicator of dysplasia/ neoplasia. Nuclear enlargement and nuclear hyperchromasia are some of the important features that take place secondary to the dysplastic or malignant transformation [23].

Cytomorphologically, well differentiated squamous cell carcinoma typically appears as individual cells or cohesive sheets of tumor cells (depending on specimen procurement method) with well defined cell borders and dense cytoplasm. Some of the cells may be tadpole, fiber or strap-shaped. There is variable N/C ratio and there may be keratin and background necrosis or ghost cells [24].

Cowpe et al. have suggested that the exfoliative cytology is capable of detecting malignant changes, through estimation of nuclear area (NA)/ cytoplasmic area (CA) using the planimeter method in Papanicolaoustained smears and concluded that 50 cells are sufficient to provide indication of malignant changes [25, 26]. Ogden et al. (1997) have also suggested that quantitative techniques, based on the evaluation of parameters such as nuclear area, cytoplasmic area, and nucleus-to-cytoplasmic area ratio (NA/CA), may increase the sensitivity of exfoliative cytology for early diagnosis of oral cancers, since these techniques are precise, objective, and reproducible [27]. Cançado et al. have concluded that the mean value for the CA and cellular diameter of keratinocytes obtained from the mucosa of normal controls was significantly greater than those of OSCC lesions. Decrease in the cellular diameter and increase in the nuclear size are two significant changes that occur in actively proliferating cell [28].

In another study by Khandelwal and Solomon (2010), oral smears were obtained from clinically normal appearing mucosa of OSCC patients and from the mucosa of smokers, and apparently healthy individuals were used as controls. They found statistically significant reduction in cytoplasmic area and increase in NA in cancer subjects when compared to normal controls, while there was a significant reduction in the CA of keratinocytes from OSCC lesion when compared with those from oral smears of tobacco users [29]. In a nutshell, these studies suggested that increased nuclear size and decreased cytoplasmic size followed by increased nuclear-cytoplasmic $(\mathrm{N} / \mathrm{C})$ ratio are useful early indicators of malignant transformation, and tobacco might have certain role in inducing change in the NA and CA in the keratinocytes of oral mucosa.

Cytomorphometrically, in all keratinized tadpole cells it is observed that the cytoplasmic areas are found to be decreased and the nuclear areas are in increased state. And thus, the nuclear-cytoplasmic (N/C) ratios are calculated to be in increasing order in our present study. The present findings not only corroborate with the earlier outcomes but also prove the validity of cytometric analysis to be an important tool for early detection of human oral carcinoma.

\section{Conclusion}

Cytological pleomorphism, no doubt, is a remarkable feature in oral neoplasia. Early detection of oral cancers is not an easy task, because in most of the cases the malignant conditions may mimic to be benign leading to delays in diagnosis and treatment. Like many cytopathologists, Kazanowska et al. fervently hope that 'Oral cytology analysis may, in the near future, be a very useful examination for patients in terms of diagnostics and monitoring, not only during the treatment but also afterwards' [30]. In the present study, it may be summarized that the genesis of moderately differentiated keratinized tadpole cells due to the metamorphosis of normal oral squamous cells is nothing but a dramatic event during oral carcinogenesis and always mimic to be a benign. But, pattern of keratinization, cellular as well as nuclear pleomorphism, mostly hyper-chromatism, micronucleation, multinucleation, nuclear haloes along with either well or ill-defined cell boundaries and with an increased nuclear-cytoplasmic (N/C) ratio in keratinized tadpole cells are the clear indication of the malignancy. Thus, appearance of KTCs irrespective of age, sex and oral sites will, no doubt, be helpful to the Cytopathologists in early detection and diagnosis of human oral carcinoma cases. 


\section{Acknowledgements}

Authors are thankful to the Head, P.G. Dept. of Zoology, Utkal University, Vani Vihar, Bhubaneshwar, Odisha for providing laboratory and library facilities; to the Director, Acharya Haihar Regional Cancer Centre (AHRCC), Cuttack, Odisha for permitting us to collect samples from the oral cancer patients and also for providing library and laboratory facilities and one of us (AM) is grateful to the University Grants Commission (UGC), New Delhi for awarding UGC Meritorious Research Fellowship to carry out the research work.

\section{References}

[1] J. Ferlay, HR Shin, F Bray, D Forman, C Mathers, D.M. Parkin, GLOBOCAN 2008 v1.2, Cancer Incidence and Mortality Worldwide: IARC Cancer Base No. 10 [Internet]. Lyon, France: International Agency for Research on Cancer, 2010. Available from: http://globocan.iarc.fr.

[2] K.R. Coelho, Challenges of the Oral Cancer Burden in India, Journal of Cancer Epidemiology, 2012, 1-17.

[3] R. Mehrotra, S. Yadav, Oral squamous cell carcinoma: etiology, pathogenesis and prognostic value of genomic alterations, Ind $J$ Cancer, 43(2), 2006, 60-66.

[4] S.C. Miller, A. Soberman, S.S. Stahl, Study of cornification of oral mucosa in young male adults, J Dent Res, 30, 1951, 4-11.

[5] P.W. Montgomery, E. von Hamm, Study of exfoliative cytology in patients with carcinoma of the oral mucosa, J Dent Res, 30, 1951, 308-313.

[6] H.G. Ahmed, A.M. Idris, S.O. Ibrahim , Study of oral epithelial atypia among Sudanese tobacco users by exfoliative cytology, Anticancer Res, 23, 2003, 1943-1949.

[7] N. G. Stromby, Experience with buccal smears in the general cytopathology laboratory, Cancer, 23, 1999, 23-26.

[8] A. Mohanta, P.K. Mohanty, G. Parida, Keratinized Spindle Cell: A Diagnostic Cytological Atypia In Human Oral Carcinoma, IOSR Journal of Dental and Medical Sciences, 13 (8), 2014, 72-80.

[9] S.Silverman, H. Becks, S.M. Farber, The diagnostic value of intra-oral cytology, J Dent Res, 37, 1977, $195-205$.

[10] S. Mulki, P Shetty, P. Pai, Cytomorphological analysis in oral squamous cell carcinoma lesions and normal controls using rub and rinse technique. Clin Cancer Investig J, 3, 2014, 38-42.

[11] R.A. Cawson The cytological smear in diagnosis of oral cancer. Brit Dent J, 108, 1960, 294.

[12] O.H. King, The cytology of common and uncommon oral malignancies. Acta Cytol, 6, 1962, 348-354.

[13] S. Pande, S.M. Ganvir, V.K. Hazarey, Rhabdomyosarcoma of the oral cavity mimicking gingival epulis: Report of two cases, J Oral Maxillofac Pathol, 7, 2003, 49-51

[14] B.O. Akinbami, O.G. Omitola, O.A. Akadiri, Pattern of presentation and management of orofacial and neck soft tissue tumors in a Nigerian tertiary health center - a preliminary study. Intern Med Inside, 1, 2013, 9. http://dx.doi.org/10.7243/2052-6954-1-9

[15] A. Singh, Role of exfoliative cytology in oral lesions: with special reference to rule out malignancy, Journal of college of Medical Sciences-Nepal, 6,(2), 2010, 29-37.

[16] W.A.D. Anderson, Anderson's Pathology, 10th Ed. (St. Louis, M.O., The C.V. Mosby Company, 1996).

[17] J.G. Nasit, G. Dhruva, Extensive squamous metaplasia with cystic change in pleomorphic adenoma: A potential diagnostic pitfall in fine needle aspiration cytology, Clin Cancer Investig J, 2, 2013, 166-169.

[18] H.C. Sandler, The detection of early cancer of the mouth by exfoliative cytology, Acta Cytol, 5, 1961,191 -194.

[19] H.C. Sandler, Reliability of oral exfoliative cytology for detection of oral cancer, J Am Dent Assoc, 68, 1964, 489-499.

[20] F. Ponte'n, M. Gry, L. Fagerberg, E. Lundberg, A. Asplund, L.Berglund, P. Oksvold, E. Bjo“rling, S. Hober, C Kampf, S. Navani, P. Nilsson, J.Ottosson, A. Persson, H.Werne'rus, K.Wester, M.Uhle'n, A global view of protein expression in human cells, tissues, and organs, Molecular System Biology,5, 2009, 1-9.

[21] A. Mohanta, P.K. Mohanty, G. Parida, Pattern of Keratinization in Oral Squamous Cells during Carcinogenesis, IOSR Journal of Dental and Medical Sciences, 13 (7), 2014, 83-91.

[22] M.M. Vaidya and D. Kanojia, Keratins: Markers of cell differentiation or regulators of cell differentiation? J Biosci, 32(4), 2007, $629-634$.

[23] E.T. McKinley, General cytologic principles. In Atkinsons BF (Ed) Atlas of Diagnostic Cytopathology, Second Edition. (Saunder, Elsevier Inc., Philadelphia, 2004).

[24] M.O. Idowu, C. N. Powers, Lung cancer cytology: potential pitfalls and mimics - a review, Int J Clin Exp Pathol, 3(4), 2010, 367385.

[25] J.G. Cowpe, Quantitative exfoliative cytology of normal and abnormal oral mucosal squames: Preliminary communication, $J$ Royal Soc Med, 77, 1984, 928-931.

[26] J.G. Cowpe, R.B. Longmore, M.W. Green, Quantitative exfoliative cytology of abnormal oral mucosal smears. J Royal Soc Med, $81,1988,509-513$.

[27] G.R. Ogden, J.G. Cowpe, A..J. Wight, Oral exfoliative cytology: Review of methods of assessment. J Oral Pathol Med, 26, 1997, 201-205.

[28] R.P. Cançado, L.S. Yurgel, M.S. Filho, Comparative analysis between the smoking habit frequency and the nucleolar organizer region associated protein in exfoliative cytology of smokers' normal buccal mucosa, Tob Induc Dis, 2(1), 2004, 43-49.

[29] S. Khandelwal, M.C. Solomon, Cytomorphological analysis of keratinocytes in oral smears from tobacco users and oral squamous cell carcinoma lesions - A histochemical approach. Int J Oral Sci, 2, 2010, 45-52.

[30] K. Kazanowska, A. Hałon, M. Radwan-Oczko, The Role and Application of Exfoliative Cytology in the Diagnosis of Oral Mucosa Pathology -Contemporary Knowledge with Review of the Literature, Adv Clin Exp Med, 23( 2), 2014, 299-305. 